\author{
(online) $=$ ISSN $2285-3642$ \\ ISSN-L = 2285 - 3642 \\ Journal of Economic Development, Environment and People \\ Volume 2, Issue 4, 2013 \\ URL: http://jedep.spiruharet.ro \\ e-mail: office jedep@spiruharet.ro
}

\title{
SUSTAINABLE QUALITY OF WORK LIFE AND JOB SATISFACTION [AN INDIAN CASE STUDY]
}

\author{
Dr Sorab Sadri* and Prof Conrad Goveas** \\ *Professor of Political Economy and Management Sciences \\ Director, School of Humanities \\ JECRC University Jaipur, Rajasthan \\ sorab.sadri2010@gmail.com \\ **Senior Faculty of Management Sciences \\ Welingkar Institute of Management Mumbai, Maharashtra, \\ conrad.goveas@gmail.com
}

\begin{abstract}
As HR experts would propound, organizational success is highly dependent on attracting, recruiting, motivating, and retaining its workforce. The quality of work life (QWL) pertains to favourable or unfavourable work environment in keeping employees motivated so as to enable increase per capita productivity. It aims at achieving an effective work place environment that satisfies both the organizational and personal needs and values of employees, promoting well being by job security, job satisfaction, development and thereby helping to maintain a better balance between work and non-work life. The word sustainability is derived from the Latin sustinere (tenere, to hold; sus, meaning up). Dictionaries provide more than ten meanings for sustain, the main ones being to "maintain", "support", or "endure". However, since the 1980s sustainability has been used more in the sense of human sustainability on planet Earth and this has resulted in the most widely quoted definition of sustainability as a part of the concept sustainable, that of the Brundtland Commission of the United Nations on March 20, 1987: "sustainable development is development that meets the needs of the present without compromising the ability of future generations to meet their needs.
\end{abstract}

Keywords: Quality of work life, job satisfaction, employee, work environment, sustainability.

JEL Codes: J28, J24, Q 56 


\author{
(online) = ISSN $2285-3642$ \\ ISSN-L = 2285-3642 \\ Journal of Economic Development, Environment and People \\ Volume 2, Issue 4, 2013 \\ URL: $\underline{\text { http://jedep.spiruharet.ro }}$ \\ e-mail: office jedep@spiruharet.ro
}

\title{
1. Introduction
}

When change is the market mantra, who thinks of sustainability? This is unfortunately the scenario in peripheral capitalist economies like India and hence we need to define our position at the outset. India is going through a Corporate Olympiad wherein change is on-linear and non Newtonian. The business scenario is marked by the concurrent collapse of structures and functions. Excellence is no longer desirable but imperative. It has to be converted into sustainability for it to be meaningful - if not would remain a colorful rainbow on the horizon that we see but cannot reach What then is sustainability? We will restrict ourselves to the dictionary meaning - to sustain or hold up. This paper attempts to provide some practical insights to enable HR departments to hold up or sustain certain parameters at satisfactory levels to maintain or enhance QWL.

The authors solicited feedback of employee's perceptions and then qualified the effects of quality of work life on employees' attitude, behaviour and performance. The paper thus aims to provide a new insight into current working life policies and practices, as well as suggest strategies to facilitate work-life balance issues of employees. Several notable and commonly agreed factors that influence qualities of work life are: (i) Safe and Healthy Working Conditions; (ii) Adequate and Fair Compensation, (iii) Opportunity to Utilize individual skills and talent, (iv) Develop Human Capabilities; and (v) provide Career and Growth Opportunities.

There is no gain saying the fact that QWL is a key aspect in balancing the relationship between work, non- work and family aspects of life. It is necessary here to qualify the distinction between Qualities of work life in particular and work life balance in general they are many a time used synonymously. However work life balance is a much larger set of which QWL could be a substantial subset. Work life balance involves all aspects of work and lire taken together as on indivisible whole. It is a dynamic concept of engagement in all aspects of living - broadly physical, mental, relational, spiritual and social to say the least. It would be pedantic to assume that all deleterious or beneficial effects in life are largely due to work dynamics alone. In fact modernity has assailed all aspects / facets of the human life - both in being and in existence. With work becoming a dominant and driving factor in modern life, QWL assumes significant importance because of its importance and impact. It can be safely presumed that satisfaction with QWL factors would definitely reduce or at least ease the burden / pressures of modern life QWL and employee job satisfaction are increasingly being identified as progressive indicators not only to the function and sustainability of business organizations. Sustainable QWL positively correlates with employee job satisfaction at work place in many situations, although not always enables people to develop knowledge, values and skills to participate in decisions about the way organizations do things, individually and collectively, locally and globally,

The HR Interface: HR departments pay attention to the aspirations of employees and evolve strategies to constantly unearth their true potential. Strategies to improve quality of work life are automatically thought about to achieve both organizational objectives and satisfy employee needs. The term Quality of Work Life (QWL) was probably coined originally at the first International Conference on 


\author{
(online) $=$ ISSN $2285-3642$ \\ ISSN-L = 2285-3642 \\ Journal of Economic Development, Environment and People \\ Volume 2, Issue 4, 2013 \\ URL: $\underline{\text { http://jedep.spiruharet.ro }}$ \\ e-mail: office jedep@spiruharet.ro
}

QWL at Arden House in 1972 (Chems and Davis 1975). Since then there has been a great degree of professional and academic attention focussed on quality of work life (QWL) as also job satisfaction of employees, both are increasingly being identified as progressive indicators related to the functioning and sustainability of business organizations (Sabarirajan, and N. Geethanjali, 2011).

Satisfaction and contentment of an individual in both work and off work aspects of life are very important in maintaining overall life balance. Quality of working life therefore is an evolved and sensitized way of thinking about people, work and organisations. Accordingly, the thrust is not only on how people can work better but also on how work and all connected with it can motivate them to do better.

Walton's conceptual 1975 model provides eight major conceptual categories relating to QWL viz. (1) adequate and fair compensation, (2) safe and healthy working conditions, (3) immediate opportunity to use and develop human capacities, (4) opportunity for continued growth and security, (5) social integration in the work organization, (6) constitutionalism in the work organization, (7) work and total life space and (8) social relevance of work life. Various scholars and researchers have proposed different definitions and models of QWL which include a wide range of factors.

It is best described as an "overall employee favourable working environment" that fosters, strengthens and sustains satisfaction by providing employees adequate rewards, reasonable job security and regular career growth opportunities (Lau Wong Chan and Law 2001) Q Quality of work life has its roots in the theories of Maslow, Herzbeg and McGregor. The needs fulfilment hierarchy of Abraham Maslow's motivational theory of needs are compatible with those of the factors of QWL use your make at. (Sadri, Jayashree and Ajgaonkar 2002).

In general terms, QWL, refers to how favourable or unfavourable are various aspects of the job and its environment for people (Davis 1983). The other techniques like quality circles, management by objectives, suggestion system and other forms of employees' participation in management also help to improve QWL to some extent. Some popular methods to improve quality of work life include job redesign, career development, flexible work schedules, job security etc. Organizations which properly adopt these techniques, may show improvement in Quality of work life be. And rapid radical changes in the world of business, through globalization, use of information technology, business competitiveness, and scarcity of natural resources have changed employee's outlook of how a good company is defined. The trend in past was to include, financial figures in defining "a good company". Latest trends like, ethics, quality of work life (QWL) and job satisfaction are now considered important predictors of sustainability and viability of business organizations (Sheel and Sindhwani 2012, Sadri and Jayashree 2013). More recent works like those of Sadri (cited above) critically look at how HR affects QWL amongst knowledge workers and their paradigms are similar to that taken in this study. Jayashree et al 2009, no doubt went further.

Basic Theorisation: Mapping the trend of thought in some definitions we find that some authors had emphasized on the physical factors of Quality of working life such as; basic extrinsic job factors of wages, hours and working conditions, and the intrinsic job notions of the nature of the work itself. He addressed other aspects, such as; fairness and equity, individual power, self development, employee participation in 


\author{
(online) = ISSN $2285-3642$ \\ ISSN-L = 2285-3642 \\ Journal of Economic Development, Environment and People \\ Volume 2, Issue 4, 2013 \\ URL: $\underline{\text { http://jedep.spiruharet.ro }}$ \\ e-mail: office jedep@spiruharet.ro
}

the management, social support, use of one's present skills, a meaningful future at work, social relevance of the work or product, effect on extra work activities. Taylor's view is holistic and all inclusive. It implies that QWL concepts may vary according to organization and employee group (Taylor Cooper and Mumford 1979).

For others since QWL was seen as a response to environmental pressures, efforts to cope with such pressures and the resultant dynamics of seeking balance will continue. The nomenclature might change but not the momentum of change will not it was argued. (Gadon 1984). Scholars like Mirvis and Lawler [1984] highlighted the fact that Quality of working life was related to satisfaction with wages, hours and working conditions, describing the "basic elements of a good quality of work life" as well as safe working environment, equitable wages, equal employment opportunities and opportunities for advancement. These appear as a bare minimum in today's hyper expectant world. Following the Tavistock Model, Rice (1985) had focussed on the relationship of work satisfaction with Quality of people's lives. He argued that work experiences and subsequent outcomes can impact person's overall Quality of life, both directly and indirectly through their impact on family interactions, leisure activities and levels of health and energy. Societies are becoming Institution Centric and employees' Organization centric. Work experiences are now a major aspect of individual life most of us. On the other hand Robbins (1989) had stated that QWL is a process through which an organization can relate and respond to employee needs by developing mechanism to allow them to be a part of the decision making processes that design their lives at work. Whilst some scholars have emphasized the psychological well being aspects in QWL, others in turn have identified the relevance of physical factors, work conditions, job opportunities and development. The bias for creating a work environment providing scope for self determination prevalent in this kind of thinking seems impractical when extrapolated to the larger context, surely many jobs today do not offer this luxury According to Danna and Griffin (1999) Quality of Work Life is a holistic concept that considers both workbased factors such as job satisfaction, satisfaction with pay and relationships with work colleagues, and also includes factors that may predictably life satisfaction and general feelings of well-being. One cannot help but discern the gradual expansion of scope and ambit whereby work satisfaction equals life satisfaction equals satisfaction with life in general. Cascio (2003) on the other hand is more concerned with time and energy spent at work should be commensurate with time and energy devoted to life, thus helping in maintaining family and career balance. He surmised that, efforts must be aimed at enhancing the overall quality of life by shifting the focus from work to life and from balance to quality. This understanding seeks to bring out deeper meaning i.e. purpose and superior essence. Such a definition brings in the element of subjectivity and idealism. Stephen and Dhanapal (2012) argue that people as prime resources constitute the core of the organisation. Organizations more often give greater importance to technology and systems than people. The fact that, it is people who drive technology and systems, in an organisation are not well remembered and even many a times forgotten. While people drive technology, let us accept that higher technology governs people in turn. This process goes on. But what is invariably missed out is the pertinent fact that technology is but a unique commodity that one buys without seeing, since if one sees it one need not buy it. (Sadri 1995). 


\author{
(online) $=$ ISSN $2285-3642$ \\ ISSN-L = 2285-3642 \\ Journal of Economic Development, Environment and People \\ Volume 2, Issue 4, 2013 \\ URL: $\underline{\text { http://jedep.spiruharet.ro }}$ \\ e-mail: office jedep@spiruharet.ro
}

In a way, it can be argued on the lines of Walton (1973) that Quality of Working Life (QWL) is a comprehensive construct that includes an individual's overall job related wellbeing and is reflected by the extent to which work experiences are considered or seen as rewarding, fulfilling, devoid of stress and other resultant negative personal consequences. The QWL concern has been increasing due to several factors. These include increase in education level and consequently higher job aspirations of employees; Association of workers to champion their interest, increasing importance of human resource management; Widespread industrial unrest due to dissatisfaction etc. Quality of Work Life refers to the level of satisfaction, motivation, involvement, and commitment individuals experience with respect to their lives at work. It is the degree to which individuals are able to satisfy their important personal needs while employed by the firm. This appears as a balanced and realistic definition rather than a normative one.

Significance of the study: The freight forwarding / custom house agencies carry out work of great variety and complexity. The nature of work requires tremendous coordination with internal and external agencies, government bodies across the world. The modes of delivery range from basic road to ship to aircraft. Myriad rules, procedures, setbacks delays and hurdles are treated as normal; yet speed and quality of service is paramount. The industry engages employees from the lowest loader to a sophisticated global logistic manager. The fact remains that employees drive the service process and delivery systems. Employees are seen as unique and the quality of their relationships as social beings, as belonging to a distinct social system is not overlooked, nor is the organizational culture. In the case of knowledge workers in the IT industry for instance the greatest HR problem was one of retention since attrition levels ranged from $20 \%$ to $35 \%$ per annum. The alternative suggested to HR was to develop corporate culture that was robust in its values and vibrant in its ethics so that the need to belong was triggered and the attrition levels were kept in check. (Jayashree, Sadri and Nayak 2009). In consonance with that line of thought this paper has examined certain common factors of QWL to gauge the satisfaction of employees towards them. The present study aims at examining the prevalence of QWL factors, as viewed by employees and their satisfaction it. The study has its uniqueness in exploring the perception of employees on QWL aspects, which is not so common.

Objectives of the study: The authors sought to identify important QWL factors by studying employee perceptions on satisfaction towards certain quality of work life parameters. In the process the following hypothesis was proffered for examination and empirical validation.

Ho: There is significant difference between employees' satisfaction and QWL of the employees.

$\mathrm{H} 1$ : There is no significant difference between employees' satisfaction and Quality of work life.

\title{
2. Methodology:
}

The study was conducted during 2011 -13 on QWL with reference to employees engaged in the freight forwarding and clearing house business in Mumbai based on the pattern of empirical research in management and social sciences. 


\author{
(online) = ISSN $2285-3642$ \\ ISSN-L = 2285 - 3642 \\ Journal of Economic Development, Environment and People \\ Volume 2, Issue 4, 2013 \\ URL: http://jedep.spiruharet.ro \\ e-mail: office jedep@spiruharet.ro
}

Sample Design: The custom house agents and freight forwards are part of an old tradition. This industry is as old as trade and has evolved over time to be a major expediting force in the world of trade: moving goods across borders, ports and open skies. Mumbai being one of the oldest British ports has been the birth place of this trade in its modern form; some of the business houses are over 100 years old and carry the legacy of cultural traditions of the past. The study confined to three companies in this segment. This industry has seen major competitive pressures due to the entry of logistics giants who are truly multinational utilizing the latest in technology and methods.

Most of the firms are privately owned and closely hold hence there is the question of confidentiality which is respected here. They have a reputation for service quality and consistency across several cities in India. They are well known and acknowledged by customers. The sample has been chosen from select freight forwarders who were gracious enough to share information on a confidential basis; despite the industry being unionised.

In all these companies there is job differentiation, yet most employees are multi-skilled i.e. there is job /task variety, yet the range of complexity varies across levels which is taken as a given. Their employees belong to all strata of society with qualifications from SSC to MBA's in operations, IT Accounts, Marketing etc. There is diversity in most aspects. Hence the sample is representative.

Table: 1 Sample selected is according to category of employees.

\begin{tabular}{|c|c|c|c|}
\hline Sr. No & Category & Total Sample & Completed Sample \\
\hline 1 & Managers & 25 & 10 \\
\hline 2 & Executives / Staff & 50 & 30 \\
\hline 3 & Field Staff & 125 & 70 \\
\hline TOTAL & & 200 & 110 \\
\hline
\end{tabular}

Data Collection: The study was confined to three companies in this segment. The three prime methods used were (i) Survey Questionnaire/ Schedule, (ii) Focused Interviews and (iii) Review of published literature. Further the authors recorded observations during the data collection and also conducted some group discussions, to understand the opinion and attitude of the respondents in general.

Methods of Data Analysis: The data collected with the help of questionnaire, which was given a code and the code book was prepared. The data was fed in excel sheets. With the data of excel sheets, the tables were then prepared, analyzed and interpreted. On the basis of the findings of the tabulated information, and observations during the data collection as recorded by the researcher conclusions were drawn out by the research investigator and certain premises have been proposed on which basis some pointed suggestions have been put for practical consideration

Scope of the study: The present study undertaken between 2011 and 2013 focuses on specific functional areas within specified limits and is restricted to employee satisfaction on QWL parameter among 


\author{
(online) = ISSN $2285-3642$ \\ ISSN-L = 2285 - 3642 \\ Journal of Economic Development, Environment and People \\ Volume 2, Issue 4, 2013
}

URL: http://jedep.spiruharet.ro

e-mail: office jedep@spiruharet.ro

the employees of this industry / service. The functional scope is restricted to the Quality of Work life among the employees. The periodical scope of the study is confined to the duration of the research. (table 2) Testing of Hypothesis:

Ho: There is significant difference between employees' satisfaction and Quality of work life.

$\mathrm{H} 1$ : There is no significant difference between employees' satisfaction and Quality of work life.

Table2: QWL Factors and the level of signification ( $P$ value)

\begin{tabular}{|c|c|c|c|c|c|c|c|c|c|c|c|}
\hline $\begin{array}{l}\text { Sr. } \\
\text { No. }\end{array}$ & QWL & actors & Agree & $\begin{array}{l}\text { Strongly } \\
\text { Agree }\end{array}$ & Uncertain & Disagree & $\begin{array}{l}\text { Strongly } \\
\text { Disagree }\end{array}$ & $x 2$ & D.F & Table Value & $\begin{array}{l}\mathrm{P} \\
\text { value }\end{array}$ \\
\hline \multirow{2}{*}{1} & \multirow{2}{*}{ Facilities } & $\begin{array}{l}\text { All Fringe } \\
\text { benefits are } \\
\text { provided }\end{array}$ & 87 & 14 & 0 & 9 & \multirow[t]{2}{*}{0} & \multirow[b]{2}{*}{83.9} & \multirow[b]{2}{*}{4} & \multirow[b]{2}{*}{$13.27 \mathrm{a}=1 \%$} & \multirow[b]{2}{*}{0} \\
\hline & & $\begin{array}{l}\text { All social security } \\
\text { benefits are } \\
\text { provided }\end{array}$ & & & & & & & & & \\
\hline \multirow[b]{2}{*}{2} & \multirow{2}{*}{$\begin{array}{l}\text { Adequacy of } \\
\text { Resources and } \\
\text { proper controls }\end{array}$} & $\begin{array}{l}\text { Resources } \\
\text { provided are } \\
\text { adequate to } \\
\text { achieve targets }\end{array}$ & 49 & 45 & 13 & 0 & 3 & \multirow[b]{2}{*}{16.1} & \multirow[b]{2}{*}{4} & \multirow[b]{2}{*}{$13.27 \mathrm{a}=1 \%$} & \multirow[b]{2}{*}{0.01} \\
\hline & & $\begin{array}{l}\text { Availability of } \\
\text { quality } \\
\text { equipment and } \\
\text { proper control } \\
\text { systems }\end{array}$ & 67 & 33 & 3 & 5 & 2 & & & & \\
\hline \multirow{3}{*}{3} & \multirow{3}{*}{$\begin{array}{l}\text { Compensation } \\
\text { and Rewards }\end{array}$} & $\begin{array}{l}\text { Compensation is } \\
\text { adequate and } \\
\text { fair }\end{array}$ & 36 & 45 & 8 & 13 & 9 & \multirow[b]{3}{*}{3808} & \multirow[b]{3}{*}{8} & \multirow[b]{3}{*}{$20.09 a=1 \%$} & \multirow[b]{3}{*}{0} \\
\hline & & $\begin{array}{l}\text { Salary is paid } \\
\text { based on job } \\
\text { responsibilities }\end{array}$ & 63 & 36 & 4 & 6 & 1 & & & & \\
\hline & & $\begin{array}{l}\text { Job performance } \\
\text { and rewards are } \\
\text { linked }\end{array}$ & 76 & 21 & 8 & 2 & 4 & & & & \\
\hline \multirow{2}{*}{4} & \multirow{2}{*}{$\begin{array}{l}\text { job satisfaction } \\
\text { and job security }\end{array}$} & $\begin{array}{l}\text { I am satisfied } \\
\text { with my job }\end{array}$ & 49 & 56 & 1 & 3 & 1 & \multirow[b]{2}{*}{15} & \multirow[b]{2}{*}{4} & \multirow[b]{2}{*}{$13.27 \mathrm{a}=1 \%$} & \multirow[b]{2}{*}{0} \\
\hline & & $\begin{array}{l}\text { I have job } \\
\text { security }\end{array}$ & 78 & 28 & 1 & 2 & 2 & & & & \\
\hline \multirow[t]{2}{*}{5} & \multirow{2}{*}{$\begin{array}{l}\text { Organization } \\
\text { culture and } \\
\text { climate }\end{array}$} & $\begin{array}{l}\text { There is } \\
\text { cooperation from } \\
\text { other } \\
\text { departments }\end{array}$ & 55 & 30 & 8 & 10 & 8 & \multirow[b]{2}{*}{18.7} & \multirow[b]{2}{*}{4} & \multirow[b]{2}{*}{$13.27 a=1 \%$} & \multirow[b]{2}{*}{0.01} \\
\hline & & $\begin{array}{l}\text { Have freedom to } \\
\text { offer comments } \\
\text { and suggestions }\end{array}$ & 72 & 32 & 4 & 3 & 0 & & & & \\
\hline \multirow{2}{*}{6} & \multirow{2}{*}{$\begin{array}{l}\text { Relation and } \\
\text { co-operation }\end{array}$} & $\begin{array}{l}\text { There are } \\
\text { harmonious } \\
\text { relationships } \\
\text { with colleagues }\end{array}$ & 42 & 52 & 13 & 2 & 1 & & & & \\
\hline & & $\begin{array}{l}\text { The Sense of } \\
\text { belongingness } \\
\text { increases with } \\
\text { cooperation }\end{array}$ & 66 & 39 & 4 & 1 & 0 & 14.8 & 4 & 13.27 & 0.01 \\
\hline
\end{tabular}




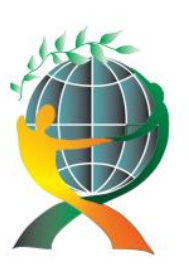

\author{
(online) $=$ ISSN $2285-3642$ \\ ISSN-L = 2285 - 3642 \\ Journal of Economic Development, Environment and People \\ Volume 2, Issue 4, 2013
}

URL: http://jedep.spiruharet.ro

e-mail: office jedep@spiruharet.ro

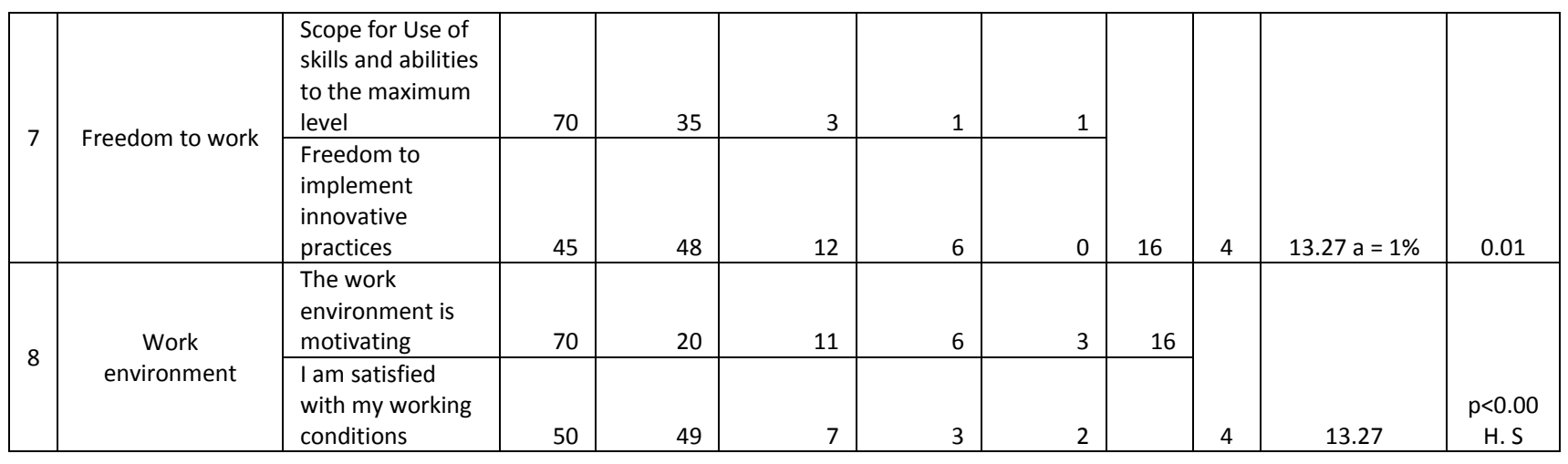

A chi-squared test, also referred to as chi-square test or $\chi^{2}$ test, is any statistical hypothesis test in which the sampling distribution of the test statistic is a chi-squared distribution when the null hypothesis is true, or any in which this is asymptotically true, meaning that the sampling distribution (if the null hypothesis is true) can be made to approximate a chi-squared distribution as closely as desired by making the sample size large enough.

As was calculated the chi-square value of each parameter above was greater than table value. Hence null hypothesis was rejected and alternative hypothesis was accepted which indicated that there is no significant difference between employees satisfaction and Work life balance According to the Wikipedia, in statistical inference of observed data of a scientific experiment, the null hypothesis refers to a general or default position: that there is no relationship between two measured phenomena, or that a potential medical treatment has no effect. Rejecting or disproving the null hypothesis - and thus concluding that there are grounds for believing that there is a relationship between two phenomena or that a potential treatment has a measurable effect - is a central task in the modern practice of science, and gives a precise sense in which a claim is capable of being proven false.

The concept of a null hypothesis is used differently in two approaches to statistical inference, though the same term is used, a problem shared with statistical significance. In the significance testing approach of Fisher, (see Box 1978) a null hypothesis is potentially rejected or disproved, on the basis of data that is significantly under its assumption, but never accepted or proved. In the hypothesis testing approach of Jerzy Neyman and Egon Pearson, a null hypothesis is contrasted with an alternative hypothesis, and these are decided between on the basis of data, with certain error rates. These two approaches criticized each other, though today a hybrid approach is widely practiced and presented in textbooks. This hybrid is in turn criticized as incorrect and incoherent. (Howie 2002)

Concluding Remarks: The present study examined the existence of QWL in select Freight forwarding companies. It revealed that $\mathrm{QWL}$ is highly prevalent as per the views of employees. Taking into 


\author{
(online) $=$ ISSN $2285-3642$ \\ ISSN-L = 2285-3642 \\ Journal of Economic Development, Environment and People \\ Volume 2, Issue 4, 2013 \\ URL: $\underline{\text { http://jedep.spiruharet.ro }}$ \\ e-mail: office jedep@spiruharet.ro
}

consideration the importance of QWL for people in the organisation, these employers should continue to take consistent and steadfast measures to sustain improve the QWL of employees. Such measures will surely benefit these employers in retaining \& sustaining their employees.

Significance of this study and its implications for HR functions in organizations: Traditionally Job satisfaction is seen as how content an individual is with his or her job. Scholars and human resource professionals generally make a distinction between affective job satisfaction (Thompson and Phua 2012) and cognitive job satisfaction (Moorman 1993). Affective job satisfaction is the extent of pleasurable emotional feelings individuals have about their jobs overall, and is different to cognitive job satisfaction which is the extent of individuals' satisfaction with particular facets of their jobs, such as pay, pension arrangements, working hours, and numerous other aspects of their jobs.

Following Moorman's 1993 work this study aimed at evaluating the perceptions of employees (a significant sample) to certain elements / factors positively associated with satisfaction at work or with work per se. In this study, aspects of the job that could be derived from the Hackman's job characteristics model, Taylor's model and Mirvis and Lawler's model which are most commonly considered from the viewpoint of HR were put together. Employee perceptions were gathered and collated. Most core dimensions / impact factors which would fall into the various factors proposed by Taylor with some intrinsic elements of Hackman's model were considered. If one looks at the segment of strong agreement, and agreement we can separate them out in a notional hierarchy from very essential to desirable. An interesting conclusion can be surmised as a future course of action, direction, or focus.

The proposition is that one can safely presume that employee satisfaction with various aspects/ dimensions of work are either connected through direct aspects /or indirect outcomes. The strength of the positive perception reveals/reflects the qualitative aspect in each dimension. One can conclude that stronger the positive perception on each dimension / aspect the higher the quality in the broadest sense. The Hackman and Oldham model postulated that the sum of the strength of all factors clubbed under each dimension would be indicative of differential quality of each dimension. Likewise we could consider the strength of the sum of these key factors as aiding in "sustainability of work life quality over a longer time span". A simple conceptual frame work will illustrate the chain of thought. If one uses time honoured Maslows (1943) hierarchy of needs as an analogy, then a representative schema may emerge as follows:

I. Physiological needs

1. Working conditions

2. Facilities

3. Equipment

II. Safety and security needs

4. Compensation and Rewards

5. Relative job security

III. Belongingness needs and self esteem needs

6. Work culture and work climate 


\author{
(online) = ISSN $2285-3642$ \\ ISSN-L = 2285 - 3642 \\ Journal of Economic Development, Environment and People \\ Volume 2, Issue 4, 2013 \\ URL: $\underline{\text { http://jedep.spiruharet.ro }}$ \\ e-mail: office jedep@spiruharet.ro
}

7. Quality of Relationships and Degree of cooperation

$I V . \quad$ Self esteem and self actualization needs

8. Freedom to innovate and use skills to fullest level

\title{
3. Conclusions
}

Suggestions to maintain sustainability and areas of focus for the HR function. The HR functions in most organizations work on several initiatives in disjointed manner. We propose that they should look at each initiative with following the hierarchy proposed below. A caveat is in order here. All we are sp... is that the degree of emphasis should be categorised as per the schema below to keep the organizational initiatives aligned with quality and sustainability. Sustainability thinking overrides qualitative thinking by emphasising aspects as essential, followed by preferential in this case instrumental, enabling, and enriching.

In order to ensure sustainability of QWL, we propose that HR professionals should focus on each area of QWL from the frame work suggested below:

I Essential Focus to be maintained at above average levels at all times.

Working conditions

Facilities

Equipment

II Instrumental Focus to be used as a lever from a situational and strategic angle.

Compensation and Rewards

Relative job security

III Enabling Focus to be worked on continuously for enhancing the first two

Work culture and work climate

Quality of Relationships and Degree of cooperation

IV Enriching Focus to bring in self determination

Freedom to innovate and use skills to fullest level

Overall motivation to work.

It would be presumptuous to suggest a hierarchy, yet HR departments can look at each aspect separately and concentrate specifically depending on the circumstances. Hypothetically speaking deficits in I and II would weaken sustainability more than deficits in III and IV. And greater strength in III and IV while keeping I and II above average would leverage quality and strengthen sustainability.

Scope for Future Research: The present study identified important QWL factors in the freight forwarding industry and employees perception on QWL factors. It has opened avenues for further study using the conceptual frame work proposed herein. The existence of QWL might be studied in different industries using the same. Also a comparative study of different organisations can be done with reference to QWL. A study could be done to find out the impact and association of QWL on productivity of 


\author{
(online) = ISSN $2285-3642$ \\ ISSN-L = $2285-3642$ \\ Journal of Economic Development, Environment and People \\ Volume 2, Issue 4, 2013 \\ URL: $\underline{\text { http://jedep.spiruharet.ro }}$ \\ e-mail: office jedep@spiruharet.ro
}

employees. The study on existence of QWL and the difference in perception by gender could also be undertaken.

\title{
4. References:
}

[1] Box, Joan Fisher (1978) R. A. Fisher: The Life of a Scientist, Wiley, New York.

[2] Cherns, A.B., and Davis, L. E. (1975) "Assessment of the State of the Art". In Davis and Cherns (Ed.), The Quality of Work Life, Vol. 1, New York.

[3] Cascio, W.F. (2003). Managing Human Resources: Productivity, Quality of Work Life, Profits. (6th ed). New York: McGraw-Hill.

[4] Danna, K. \& Griffin, R. W. (1999). Health and well-being in the workplace: A review and synthesis of the literature. Journal of Management, 25, 357-384.

[5] Davis, L.E. (1983): “Learning from the Design of New organisation”. in H.F Kolodny and H.Van Beinum (eds.), the Quality of Working Life and the 1980s, New York: Praeger,

[6] Gadon Herman (1984), "Making sense of Quality of work life programs", Business Horizons, Vol. 27(1), 42-46.

[7] Hackman J R and Oldham G R (1976). "Motivation through design of work".Organizational behaviour and human performance 16 (2): 250-279.

[8] Howie, David (2002) Interpreting Probability: Controversies and Developments in the Early Twentieth Century Cambridge University Press, London

[9] Jayashree S (2005): What Every MBA Should Know About HRM, Himalaya Publishing Co., Mumbai.

[10] Jayashree S, Sadri S and Nayak N (2009): A Strategic Approach to Human Resources Management, Jaico Publishing Co., Delhi

[11] Lau, T, Wong, H.,. Chan K.F and Law, M. (2001), Information Technology and the Work Environment-Does it Change the Way People Interact at Work, Human Systems Management, 20(3), 267-280.

[12] Maslow, A.H. (1943). A Theory of Human Motivation. Psychological Review, 50(4), 370-96.

[13] Mirvis P.H and Lawler, E.E. (1984), Accounting for the Quality of Work Life, Journal of Occupational Behaviour, 5, 197-212.'

[14] Moorman, R.H. (1993). "The influence of cognitive and affective based job satisfaction measures on the relationship between satisfaction and organizational citizenship behaviour". Human Relations 6: 759-776.

[15] Neyman, J and Pearson, E. S. (1933): "On the Problem of the Most Efficient Tests of Statistical Hypotheses". Philosophical Transactions of the Royal Society A: Mathematical, Physical and Engineering Sciences 231 (694-706): 289

[16] Rice, R. W., (1985) Organizational Work and the Perceived Quality of Life towards a Conceptual Model, Academy of Management Review, April, Col. 10(2), , pp 296310.

[17] Robins, S P (1989) Organizational Behaviour: Concepts, Controversies, and Applications, New Jersey, Prentice Hall,

[18] Sabarirajan, and Geethanjali, N (2011) A Study on Quality of Worklife \& Organizational Performance among the employees of Public \& Private Banks in Dindigul, International. Journal. Of Economic. Research. 2(6), 38 -45 ,

[19] Sadri S, Jayashree S and Ajgaokar M (2002): Geometry of HR, Himalaya Publishing Co., Mumbai 


\author{
(online) $=$ ISSN $2285-3642$ \\ ISSN-L = $2285-3642$ \\ Journal of Economic Development, Environment and People \\ Volume 2, Issue 4, 2013 \\ URL: http://jedep.spiruharet.ro \\ e-mail: office jedep@spiruharet.ro
}

[20] Sadri S and Jayashree S (2011) Business Ethics and Corporate Governance, Current Publications, Agra

[21] Sadri S and Makkar U (eds) (2012): Future Directions in Management, Bharati Publications, Ghaziabad.

[22] Sadri S and Jayashree S (2013): Human Resources Management in Modern India (concepts and cases), Himalaya Publishing Co., Mumbai

[23] Sheel Shalini, Sindhwani Bhawna Goel Shashank, and Pathak, Sunil (2012) International Journal of Multidisciplinary Research Vol.2 Issue 2, February

[24] Stephen A and Dhanapal, D (2012), Quality of Work Life in Small Scale Industrial Units: Employers and Employees Perspectives, European Journal of Social Sciences ISSN 1450-2267 Vol.28 No.2 pp. 263.

[25] Taylor, J.C.. Cooper C.L and. Mumford E, (1979). The quality of working life in Western and Eastern Europe, Algemeen Burgerlijk Pensioenfonds, Europe

[26] Thompson, E.R.and Phua F.T.T. (2012). "A Brief Index of Affective Job Satisfaction". Group \& Organization Management 37 (3): 275-307

[27] Walton, R.E. (1975) Criteria for Quality of Working Life, In L.E. Davis, A.B. Cherns and Associates (Eds.), The Quality of Working, New York, The Free Press, Life, 1, 91-104. 